\title{
УДК 747.012
}

\section{APPLICATION OF UKRAINIAN TRADITIONAL MOTIVES OF DECORATIVE AND APPLIED ART IN THE INTERIOR OF CATERING ESTABLISHMENTS IN UKRAINE ЗАСТОСУВАННЯ УКРАЇНСЬКИХ ТРАДИЦЙНИХ МОТИВІВ ДЕКОРАТИВНО- УЖИТКОВОГО МИСТЕЦТВА В ІНТЕР'ЄРІ ЗАКЛАДІВ ГРОМАДСЬКОГО ХАРЧУВАННЯ НА ТЕРЕНАХ УКРАЇНИ}

Konopatska D.S. / Конопатська Д.C. student of a baccalaureate / cтудент-бакалавр групи Д3-43

Petrovska Yu.R. / Петровська Ю.P Phd / к.арx.,cm..викл. ORCID: 0000-0001-8519-7065

Lviv Polytechnic National University, Stepan Bandera street 12, 79013 Національний університет «Львівська політехніка», Львів, вул. Ст. Бандери, 12, 79013

Анотація. У статті висвітлено вітчизняний досвід використання традиційних мотивів декоративно-ужиткового мистецтва в інтер'єрі закладів громадського харчування. Проілюстровано реалізовані проекти дизайну інтер'єрів на теренах України. Розкрито принципи формування сучасних інтер'єрів закладів громадського харчування та особливості використання в них предметів декоративно-ужиткового мистецтва.

Ключові слова: дизайн інтер'єру, декоративно-ужиткове мистецтво, заклади громадського харчування.

Актуальність теми. 3 часів здобуття незалежності України та, особливо після Революції Гідності, спостерігається етнічне відродження, що виражається особливим зацікавленням та прагненням людей у пізнанні власної національної ідентичності, історії, культури, побуту та традицій. Досить актуальними на сьогоднішній день є твори та мотиви декоративно-ужиткового мистецтва, які беруть участь в оформленні інтер'єрів закладів громадського харчування. Саме елементи декоративно-ужиткового мистецтва формують одні 3 головних художніх акцентів, генерують основну стилістичну ідею та збільшують виразність інтер'єру закладу. Перед дизайнерами постає важливе завдання створення своєрідного взаємозв'язку між поколіннями, завдяки застосуванням українських мотивів та творів декоративно-ужиткового мистецтва в інтер'єрах закладів громадського харчування; організація гармонійного, психологічного та комфортного середовища; передача в інтер'єрі основні етнічних, національних традицій та особливостей народу, використовуючи природні матеріали, колір, пластичність та орнаменти.

Вітчизняний досвід використання традиційних мотивів декоративноужиткового мистецтва в інтер'єрі закладів громадського харчування. В інтер'єрі ресторану «MED» у Києві (Рис.1), автори дизайн-проекту Sergey Makhno Arhitects втілили естетичний принцип японської простоти, гармонії 3 природою «Вабі-Сабі», що в перекладі означає «скромна простота». В одному інтер'єрі дизайнери поєднали лаконічні та скромні японські форми та українську імпульсивність. Уособленням української естетики в інтер'єрі ресторану виступають яскраві та самобутні етноформи. У використанні 
кераміки, різьби та автентичних орнаментів відчувається символізм, а саме «міст» між поколіннями. Основним джерелом натхнення у формування інтер'єру стала культура Трипілля. Авторами проекту використані меблі, стилізовані під традиційні, такі як світильники, барна стійка та піч. Виготовлені 3 кераміки елементи декоративно-ужиткового мистецтва - використані в оздоблені інтер'єру закладу. Основним акцентом ресторану став світильник «Бубонці», авторська розробка Сергія Махно.
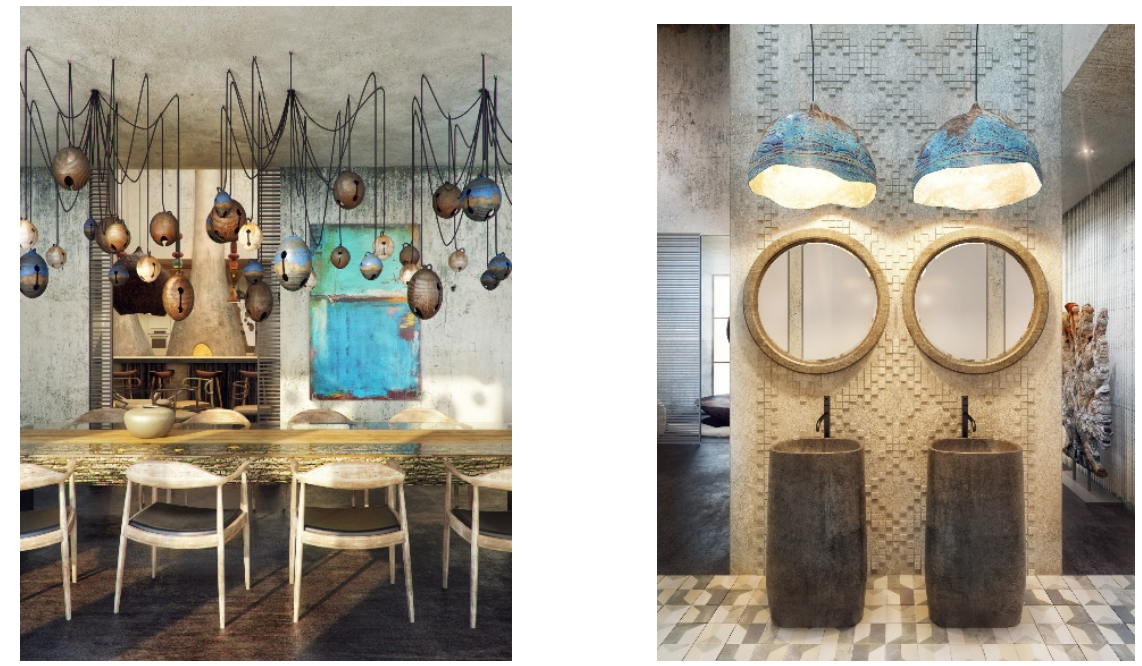

Рис.1. Ресторан «MED» (автор-Sergey Makhno Arhitects), м.Київ, Україна [1].

Декоративним елементом, що відтворений на окремих стінах закладу, виступає традиційний український орнамент. У підсумку, авторський колектив створив вишуканий інтер’єр ресторану «MED», 3 недосконалими формами, приглушеними кольорами, відкритими текстурами та із традиційними етномотивами, які милують око відвідувачів закладу, випромінюючи спокій та формують свою власну історію [1].

Ресторан «100 років тому вперед» розташований в історичному центрі Києва, на вулиці Володимирській. В його назву вкладений основний задум авторів проекту Balbek Bureau - переосмислити традиційні українські страви та інтегрувати своє бачення у сучасному інтер'єрі, створивши умовний зв'язок між історичним минулим та швидко прогресуючим сьогоденням України. Окрім сформованих інтер'єрів двох залів, що розташовані на двох поверхах, у ресторані запроектували кухню, в якій побудовано спеціальну за автентичними принципами і простором для ферментацій.

Стіни, підлога та меблеві групи оздоблені світло-охристими відтінками із вкрапленнями червоного кольору, оскільки саме така кольорова гамма притаманна традиційним українським орнаментам. Основними акцентами в інтер'єрі стали великий обідній стіл та лавки білого кольору, котрі традиційно використовувалися нашими предками в давні часи. Для створення особливої атмосфери у закладі, в інтер'єрах використали живі рослини, сезонні овочі та сухоцвіти, притаманні українським регіонам, зокрема папороть, цибулю та колосся пшениці. В інтер'єрі здебільшого застосовані натуральні матеріали: масив дубу на підлозі, справжні бруси дерева та метал [2]. 

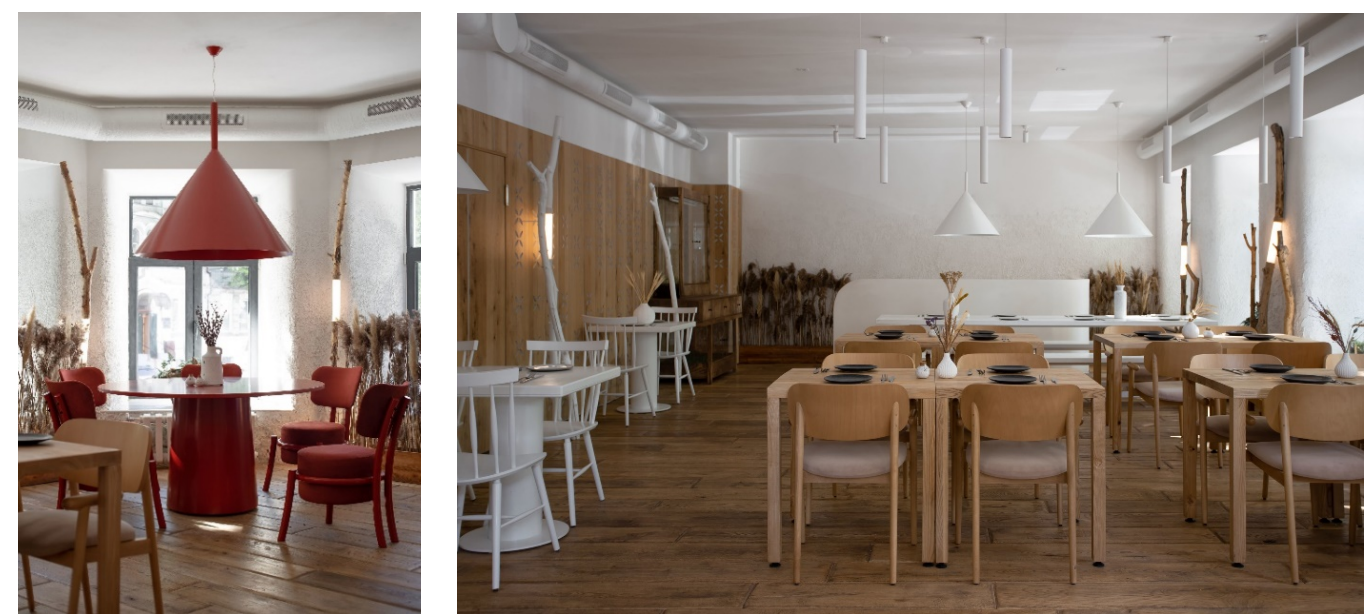

\section{Рис. 2. Ресторан «Сто Років Тому Вперед» (автори - студія Balbek Bureau), м. Київ, Україна [2].}

Інтер’єр ресторану «Salo Bar» у місті Києві, вдало поєднав у собі елементи декоративно-ужиткового мистецтва, «хату-мазанку» та сучасний лофт 3 гармонійними колірними рішеннями, адаптованими під сучасного споживача.

Основними елементами, що формують дизайн в інтер'єрі ресторану є м'які дивани, подушки і стільці, доповнені текстилем з традиційним гуцульським орнаментом, керамічні та плетені з лози світильники, а також дерев'яні меблі 3 ефектом старіння. Доповненням служать ткані килими розташовані на стінах. В оздобленні стін використано очищену від штукатурки цегляну кладку, яка у деяких місцях є пофарбована білою фарбою [3].
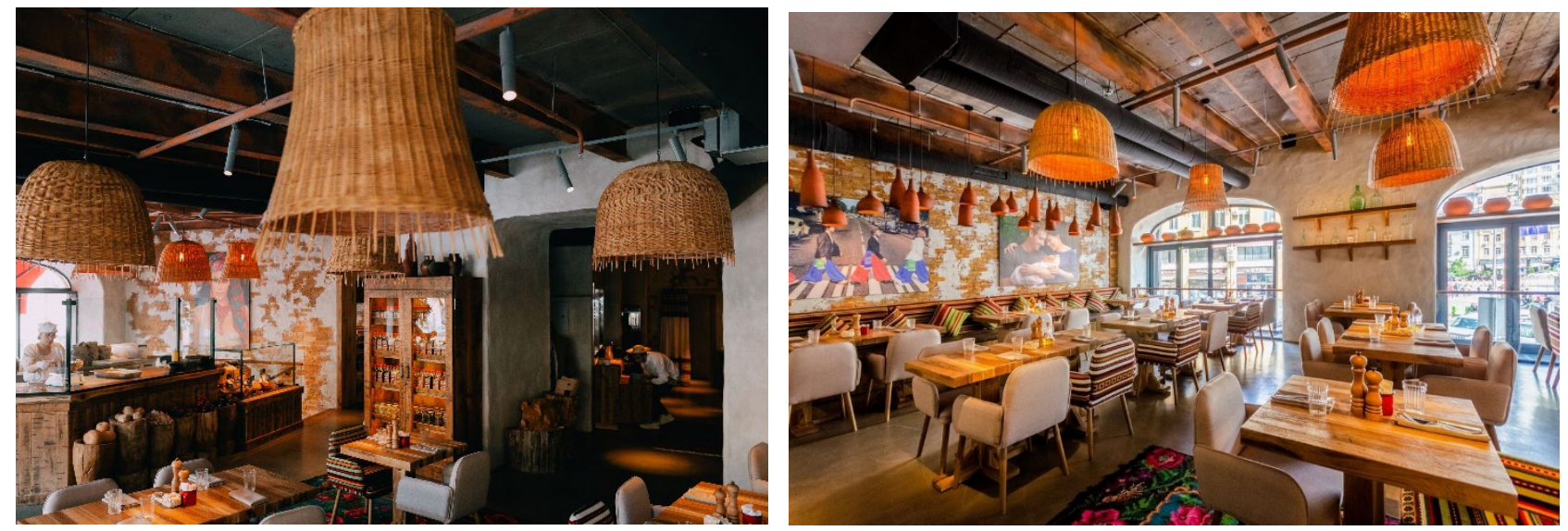

Рис. 3. Ресторан «Salo Bar». м. Київ, Україна [3].

В інтер'єрі закладу ресторану «Родичі», розташованого у місті Жашків (автори - студія Loft Buro), відчувається зв'язок з місцевістю та історією центральної частини України. Кожен із використаних матеріалів в інтер'єрі, а саме вітраж, вишивка, орнамент підкреслюють автентичність українських традицій. Стеля закладу прикрашена традиційним орнаментом - вишивкою хрестиком.

Меблі в інтер'єрі закладу, а саме обідні столи виконані з натурального дерева, стільці-крісла та м'які дивани оббиті тканиною з етнічним орнаментом, який використовували у тканих килимах. Основним акцентом виступає камін, 
розписаний народним символом та оберегом - деревом життя. Кожен елемент декору доповнює та підкреслює атмосферу ресторану 3 традиційними українськими мотивами [4].
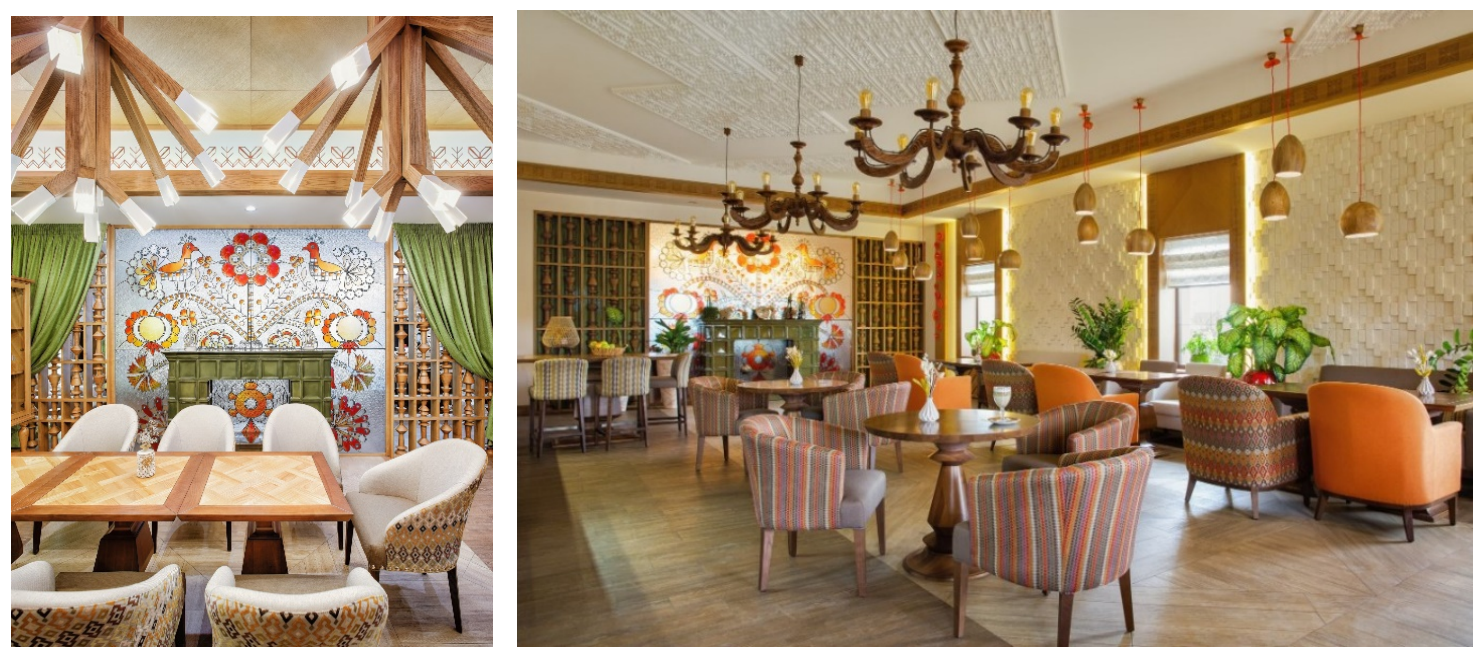

Рис. 4. Ресторан «Родичі» м. Жашків (автори-студія Loft Buro), Україна [4].

\section{Характерні особливості та елементи декоративно-ужиткового} мистецтва в інтер'срі закладів громадського харчування. Українське декоративно-ужиткове мистецтво є різнобічним, багатогранним та складним художнім явищем, яке має свій сенс та свою декоративну образність. Це створення та оформлення художнього образу, що є складовим оточуючого середовища людини і має безпосередній зв'язок з побутовими потребами. Виготовляють їх з різноманітних натуральних матеріалів таких як, дерево, скло, глина, метал, тканина та шкіра, тому класифікація творів декоративноужиткового мистецтва проходить в основному за матеріалом і технологією виготовлення.

Основними напрямками декоративно-ужиткового мистецтва $\epsilon-$ художня обробка каменю, дерева i металу, ткацтво, килимарство, гончарство, декоративний розпис та художня вишивка. Саме ці твори декоративноужиткового мистецтва виступають основними засобами декорування сучасного інтер'єру, що міститить елементи етностилю.

Висновки. Прикладом оформлення інтер'єрів закладів громадського харчування традиційними та стилізованими елементами декоративноужиткового мистецтва в Україні є ресторани «MED», «100 років тому вперед», «Salo Bar» та ресторан «Родичі». Усі ці проекти об'єднує використання в свої інтер'єрах екологічних, натуральних матеріалів, традиційних керамічних виробів, народних орнаментів та кольорова гамма яка притаманна традиційним українським мотивам. У деяких інтер'єрах використовуються тканини 3 етнічним орнаментом які використовували у традиційних українських тканих килимах.

Література:

1. MED. Sergey Makhno Architects [Електронний ресурс] // Behance.net. Режим доступу: https://www.behance.net/gallery/33828852/MED 
2. 100 ROKIV TOMU VPERED [Електронний ресурс] // Balbek Bureau. Режим доступу: https://www.balbek.com/100-rokiv-tomu-vpered

3. Не только о сале: чем влюбляет в себя новый Salo Bar? [Електронний pecypc] // Maincream.com. - Foodstyle. - Режим доступу:

https://maincream.com/ru/category/contentcategoryfoodstylehtml/1988/ne-tolko-osale-cem-vlublaet-v-seba-novyj-salo-bar

4. Rodychi [Електронний pecypc] // loft buro. - Режим доступу: https://loftburo.com/projects/rodychi/

\section{References:}

1. MED. Sergey Makhno Architects [Electronic resource] // Behance.net. - Access mode: https://www.behance.net/gallery/33828852/MED

2. 100 ROKIV TOMU VPERED [Electronic resource] // Balbek Bureau. - Access mode: https://www.balbek.com/100-rokiv-tomu-vpered

3. Not just about fat: what does the new Salo Bar fall in love with? [Electronic resource] // Maincream.com. - Foodstyle. - Access mode:

https://maincream.com/ru/category/contentcategoryfoodstylehtml/1988/ne-tolko-o-sale-cemvlublaet-v-seba-novyj-salo-bar

4. Rodychi [Electronic resource] // loft buro. - Access mode: https://loftburo.com/projects/rodychi/

Abstract. The article shows the domestic experience of using traditional motifs of decorative and applied arts in the interior of catering establishments. Illustrated the realized projects of interior design on the territory of Ukraine. The principles of formation of modern interiors of public catering establishments and features of their use of decorative and applied art are revealed.

Key words: interior design, decorative and applied arts, catering establishments.

Статья отправлена: 15.12 .2020 p.

(C) Конопатська Д.С., Петровська Ю.Р. 